\title{
Cztery nieznane listy Aleksandra Linowskiego do Adama Kazimierza Czartoryskiego (1804-1805) ${ }^{1}$
}

\author{
Bożena Mazurkowa \\ (Uniwersytet Śląski w Katowicach)
}

Aleksander Linowski (ok. I76o-ı82o), syn wojskiego nowokorczyńskiego Prokopa $^{2}$ i Tekli z Miruckich, to jedna z ważnych postaci polskiej sceny politycznej schyłku XVIII i początków XIX wieku³. Uczęszczał do Akademii Krakowskiej (I77I), Królewskiego Collegium Nobilium w Warszawie (I773/I774), a finansowa pomoc Stanisława Augusta pozwoliła mu uzupełnić wykształcenie w Berlinie (I786-I787). Karierę polityczną rozpoczął od posłowania z ziemi krakowskiej na sejm grodzieński i784 roku, a następnie na Sejm Wielki jako podkomorzy nadworny. W tym ostatnim okresie blisko współpracował z polskim władcą; spod jego pióra wyszły Uwagi nad projektem praw konstytucyjnych ${ }^{4}$. Za rządów targowicy przebywał głównie w swoich dobrach w Galicji i w Krakowie, gdzie 24 marca I794 roku na Rynku w obecności Tadeusza Kościuszki odczytał „akt powstania”.

1 We wprowadzeniu do edycji listów wykorzystane są wątki podjęte w rozprawie poświęconej tej korespondencji: B. Mazurkowa, O emocjonalnych i towarzyskich aspektach listórw Aleksandra Linowskiego do Adama Kazimierza Czartoryskiego, w: Epistolografia w dawnej Rzeczypospolitej, t. 7: Literatura, bistoria, jezzyk, red. P. Borek i M. Olma, Kraków 2017, s. 127-140.

2 Zob. Urzędnicy wojerwództwa sandomierskiego XVI-XVIII wieku. Spisy, t. 4, z. 3: Matopolska (województwa krakowskie, sandomierskie i lubelskie), oprac. K. Chłapowski, A. Falniowska-Gradowska, red. A. Gąsiorowski, Kórnik 1993, s. 46.

3 Podstawowe informacje biograficzne podaję za: A. Woltanowski i M. Złomska, Linowski Aleksander, w: Polski stownik biograficzny, t. 17, z. 3, Kraków 1972, s. 377-381. Ważnym źródłem wiedzy o kolejach życia i karierze Linowskiego jest poświęcony mu odrębny, dość duży rozdział we wspomnieniach Kajetana Koźmiana, Pamiętniki, t. 2, przedmowa A. Kopacz, wstęp i komentarz J. Willaume, wstęp edytorski, ustalenie tekstu w oparciu o autograf oraz komentarz filologiczny M. Kaczmarek i K. Pecold, Wrocław 1972, s. 246-271.

4 Zob. J. Dihm, Sprawa Konstytucji Ekonomicznej z 1791 r. (Na tle wewnętrznej i zagranicznej sytuacji Polski), Wrocław 1959, s. 105-114, 116-129; E. Rostworowski, „Marzenie dobrego obywatela”, czyli królewski projekt Konstytucji, w: idem, Legendy i fakty XVIII w., Warszawa 1963, s. 373, 402-405.

5 Zob.W.Łukaszewicz, Targowica ipowstanie kościuszkowskie. Zestudiów nad historiq Polski XVIII wieku, Warszawa 1953, s. 200. 
Następnie organizował zryw w mieście i był pierwszym sekretarzem Naczelnika. W okresie porozbiorowym kontynuował karierę polityczną i urzędniczą. W roku I8I7, po dwóch latach pełnienia funkcji dyrektora generalnego policji w Komisji Spraw Wewnętrznych i dyrektora poczt zwolniono go ze służby. Zmarł w roku I820 w Warszawie jako senator-kasztelan ${ }^{6}$.

Jak już wspomniano, po trzecim rozbiorze Linowski przeniósł się do swoich dóbr krakowskich. Pędził tam „życie spokojne”, oddawał się „towarzystwu ludzi uczonych" wcześniej zetknął się w okresie Sejmu Czteroletniego, gdy był pośrednikiem między królem a stronnictwem patriotycznym. Utrzymywał też wówczas bliższe kontakty z rodziną Czartoryskich. Wyjeżdżał do Puław, gdzie salon prowadziła Maria Wirtemberska, a także odwiedzał Sieniawę, ,gdzie stale oddychano patriotyzmem i gdzie się zwykło było zgromadzać najświetniejsze i z wychowania, i z ojczystych uczuciów obojej płci towarzystwo" ${ }^{8}$. W tej galicyjskiej posiadłości książę Adam Kazimierz przebywał okresowo do połowy pierwszej dekady XIX wieku, a na stałe po uzyskaniu nominacji na feldmarszałka austriackiego (I805) ${ }^{9}$.

$Z$ tego okresu pochodzą nieznane dotąd, zachowane w Bibliotece Książąt Czartoryskich w Krakowie, cztery listy Aleksandra Linowskiego do księcia Adama Kazimierza, wzbogacające stosunkowo niewielki zasób jego korespondencji ${ }^{\text {Io }}$. Brak informacji o nich w Bibliografi literatury polskiej „Nowy Korbut”, w Polskim stowniku biograficznym, w katalogu krakowskiej książnicy, a także w publikacjach Aliny Aleksandrowicz na temat kręgu Puław oraz Marii Wirtemberskiej. Karty zapełnione dość czytelnym, równym pismem zawierają liczne wtrącenia w języku francuskim.

6 Ludzie z epoki pochlebnie pisali o ważnych dla działalności publicznej umiejętnościach i uzdolnieniach Linowskiego, ale negatywnie postrzegali jego koniunkturalność, zbytnie skupienie na partykularnych interesach. Nie kwestionowano jego patriotyzmu, ale zwracano uwagę na zachowawczą postawę, interesowność, pogoń za splendorami i poklaskiem oraz zapobiegliwość w nawiązywaniu znajomości i przyjaźni umożliwiających urzędniczą karierę, która zapewniała dość wysokie dochody. Zob. J.U. Niemcewicz, Pamiętniki czasów moich, t. 2, tekst oprac. i wstępem poprzedził J. Dihm, pierwsze wyd. według obszerniejszej wersji rękopiśmiennej, Warszawa 1957, s. 278, 279; K. Koźmian, Pamiętniki, t. 2, s. 246.

7 Zob. K. Koźmian, Pamiętniki, t. 2, op. cit., s. 248.

8 Ibidem.

9 H. Waniczkówna, Czartoryski Adam Kazimierz, w: Polski stownik biograficzny, t. 4, Kraków 1938, s. 255.

10 W znanym dotąd zasobie korespondencji Linowskiego znajdują się jego listy do: Stanisława Augusta, Aleksandra Benedykta Batowskiego, Antoniego Horodyskiego, Stanisława Staszica, Juliana Ursyna Niemcewicza oraz do cara Aleksandra I i Nikołaja Nowosilcowa, a także od Tadeusza Aleksandra Wawrzeckiego, Jana Śniadeckiego i Zofii Oborskiej. Zob. Bibliografia literatury polskiej „Nowy Korbut”, t. 5: Oświecenie. Hasta osobowe I-O, oprac. E. Aleksandrowska z zespołem, red. tomu do r. 1958 T. Mikulski, Warszawa 1967, s. 261 (hasło: Linowski Aleksander (ok. 1759-1820)); t. 6, cz. 2: Oświecenie. Uzupetnienia, indeksy, oprac. E. Aleksandrowska z zespołem, Wrocław 1972, s. 169 (hasło: Linowski Aleksander). 
Zostały włączone do jednej z teczek korespondencji Ludwika Kropińskiego z księciem Adamem Jerzym Czartoryskim. Trzy listy zamykają inicjały „A. L.”, a ostatni opatrzony jest skróconym podpisem: „Aleks. Linowski”. Wszystkie zostały wysłane z Krakowa, a datowane są na 30 maja, 2I października i Ir listopada I804 roku oraz 5 marca roku następnego ${ }^{\text {II }}$. Jak się wydaje, Linowski wysyłał je do Puław. W przypadku ostatniego listu świadczy o tym powołanie się na odebraną stamtąd właśnie wiadomość o dobrym zdrowiu i samopoczuciu Czartoryskiego. W odniesieniu do dwóch poprzednich przesyłek w sposób pośredni na adres puławski wskazuje kwestia związana najpierw z dostępnością, a później z dostarczeniem adresatowi nowej publikacji Jana Śniadeckiego. W przypadku tej pierwszej, opatrzonej datą II listopada I804 roku, dodatkowo to przypuszczenie wspiera fragment dotyczący prezentu od księżnej Izabeli. Jedynie w odniesieniu do listu z 30 maja I804 roku można by przypuszczać, że został wysłany do Sieniawy, aczkolwiek równie prawdopodobne są Puławy.

Odnaleziona korespondencja świadczy o znacznie silniejszych więziach emocjonalnych między Linowskim a księciem generałem, niż w dotychczasowych publikacjach naukowych sugerują lakoniczne uwagi na temat bywania pierwszego z nich w domu Czartoryskich, także w sieniawskiej posiadłości. $Z$ całym szacunkiem dla wieku i społecznego statusu adresata, a także zgodnie $z$ obowiązującą etykietą, nie tyle jednak z przejawami uniżoności wobec niego (z racji uprzywilejowanej pozycji magnata), lecz z wyraźnymi akcentami świadczącymi o przyjaznych, bliskich relacjach kierował on do generała ziem podolskich zbliżone formuły salutacyjne i apostroficzne: „Mci Książę Dobrodzieju”, „JOMci Książę Dobrodzieju, „mój Książę”. Niezmiennie też (chociaż nie zalecały tego ówczesne listowniki) po polsku i po francusku upadał do nóg „WKsMci Dobrodzieja” ${ }^{2}$. W czterech listach liczne są wypowiedzi, które świadczą o serdeczności w stosunku do siedemdziesięcioletniego adresata. Potwierdzają to drobne przysługi Linowskiego dla nestora rodu, jak choćby świadczące o bystrości i sprycie rozpoznanie na rynku win w Krakowie, zakup i przesłanie dzieła Jana Śniadeckiego o „geometrii astronomicznej”, zdobywanie wiadomości na temat konkretnych osób (Franciszka Słonińskiego, Watsonów). W zamian autor korespondencji otrzymał od adresata ważny dla niego list polecający do pruskiego generała księcia Ludwika Ferdynanda I Hohenzollerna, a od księżnej Izabeli piękne konie w podarunku. Należy

11 Teczka, w której znajduje się korespondencja Aleksandra Linowskiego do Adama Kazimierza Czartoryskiego, oznaczona jest w zbiorach Biblioteki Książąt Czartoryskich w Krakowie numerem III 5535. Oto lokalizacja listów w tym rękopiśmiennym zbiorze: 21 maja 1804 - s. 21-24; 21 października 1804 - s. 25-26; 11 listopada 1804 - s. 27-28; 5 marca 1805 - s. 29-32.

12 Zob. K. Mroczek, Tytulatura w korespondencji staropolskiej jako problem stosunku między nadawca a odbiorcq, „Pamiętnik Literacki” 1978, z. 2, s. 129-146. 
tu dobitnie podkreślić, że listowne rozmowy Linowskiego z Adamem Kazimierzem Czartoryskim przebiegają w aurze intymności znacznie wykraczającej poza obowiązujące już od czasów staropolskich ramy tego modelu grzeczności, który realizowali w kontaktach wewnątrzgrupowych przedstawiciele społeczności szlacheckiej, zwłaszcza w stosunku do osób cieszących się wysokim szacunkiem i społecznym autorytetem ${ }^{\mathrm{I} 3}$.

Po inicjalnej części stricte prywatnej Linowski zwykle dzielił się z adresatem przemyśleniami, które, jak się wydaje, korespondowały z problematyką podejmowaną przez księcia w listach. Wiązały się z szeroko rozumianym życie literackim i kulturalnym, dotyczyły publikacji polskich i zagranicznych autorów, samego warsztatu pisarzy i tłumaczy oraz wartości poznawczej ich publikacji (m.in. przekładów Franciszka Słonińskiego, tekstów Józefa Maksymiliana Skoraszewskiego, dzieła francuskiego historyka, naukowej pracy Jana Śniadeckiego czy inicjatyw Franciszka Ksawerego Dmochowskiego). W kontekście refleksji z tego obszaru Linowski jeden raz, w liście z II listopada I804 roku, z pewnym żalem odniósł się do własnego talentu, o który (w swoim przekonaniu) nie zadbał dostatecznie. Wprawdzie faktycznie nie osiągnął jakichś spektakularnych sukcesów, ale też nie miał ich tak zupełnie mało, skoro w roku I806 Towarzystwo Przyjaciół Nauk przyjęło go w poczet swoich członków. Był ostrym polemistą i krytykiem sejmowym, autorem kilku mów poselskich ujawniających wybitny talent oratorski ${ }^{14}$, a także dwóch oracji funeralnych. Napisał paszkwil List przyjaciela odkrywajacy wszystkie czynności Kotłątaja w ciagu insurekcji pisany roku r795, powstałe w kręgu puławskiego salonu Marii Wirtemberskiej wiersze: „Nie mieć na przyszłość życzenia...” oraz Herbata $z$ winem ${ }^{\mathrm{I5}}$, odę Wezwanie do Światyni przy jej otwarciu ${ }^{\mathrm{I}}$, utwór narracyjny Piękność i dobroć. Powieść... w roku I795 (inc. „Gdy osobiście spotkać się zdarzyło...”) oraz wdzięczny liryk-pasterkę Zosia (inc. „Noc nad światem górę bierze...”) ${ }^{\mathrm{I7}}$, a w późniejszym okresie wiersze Do cesarzowej rosyjskiej matki podczas jej bytności w Warszawie I8I8 i Do ks. Jaszerwskiego.

13 Zob. M.Wojtak, Wybrane elementy staropolskiej etykiety jezykowvej, „Język a Kultura”, t. 6: Polska etykieta jezykowa, red. J. Anusiewicz i M. Marcjanik, Wrocław 1992, s. 34.

14 Zob. B. Krakowski, Oratorstwo polityczne na forum Sejmu Czteroletniego. Rekonesans, Lublin 1968, s. 103.

15 Zob. A. Aleksandrowicz, Z kręgu Marii Wirtemberskiej. Antologia, teksty rękopisów wybrała, oprac. i wstępem poprzedziła A. Aleksandrowicz, Warszawa 1978, s. 123, 125-127.

16 Zob. m.in. eadem, Wprowadzenie do lektury. Patriotyczny etos Światyni Sybilli, w: Opisy niektórych pamiatek zachowanych w Światyni Sybilli w Putawach, wyd. A. Aleksandrowicz i A. Timofiejew, Warszawa 2010, s. 8.

17 Te dwa liryki opublikowane w „Tygodniku Polskim” w latach 1819-1820 zlokalizował Wiesław Pusz („Nowy Parnas” przedromantycznej Warszawy. Bruno Kicinski i grono jego wspótpracowników, Wrocław 1979, s. 215). 
Pisarskie umiejętności Linowskiego w dużej mierze decydują o sugestywnym i wzruszającym zarazem ujmowaniu przez niego uczuć do Czartoryskiego, a także o barwnej, zróżnicowanej pod względem stylu stricte informacyjnej części charakteryzowanych tu listów. Jak bowiem rozmaite tony ożywały pod piórem Linowskiego literata, tak też różne rozbrzmiewają w jego listach do księcia Czartoryskiego, eksponując emocjonalne aspekty tej korespondencji. Jest tu i powaga, i elementy sensacyjności, i naznaczona ciepłem żartobliwość. W stosunku do przebywającego w Sieniawie seniora rodu Czartoryskich Linowski odgrywał $\mathrm{w}$ dużej mierze rolę przyjaznego informatora, dostarczającego wiadomości o tym, co działo się w towarzyskich kręgach Krakowa i jaki w tym środowisku był rezonans wydarzeń rozgrywających się wówczas na politycznej scenie Europy. Jego listy w części zbliżone są zatem do powstających w epoce gazetek pisanych $^{\mathrm{I} 8} \mathrm{i}$ bez wątpienia ubarwiały księciu czas spędzany w Sieniawie, biegnący innym rytmem niż w mieście. Wieściami różnymi starał się Linowski zaciekawić, zaskoczyć, a nawet rozbawić księcia, darzonego przezeń autentycznym szacunkiem, wdzięcznością i wielkim uznaniem za ogromne dzieło jego życia, a przy tym bezinteresowną, szczerą serdecznością. Wszystkie te intencje i zamiary autor ujawniał $\mathrm{w}$ listach $\mathrm{w}$ aurze radości czerpanej $\mathrm{z}$ bycia pomocnym nestorowi rodu oraz spędzania czasu z człowiekiem o szczególnych walorach etycznych, moralnych i wielkim sercu. I z tym ostatnim aspektem pięknie powiązał Linowski swoje marzenia o przyszłości w końcowej części czwartego listu, gdzie w ostatnim zdaniu deklarował się jako „wiecznie przywiązany duszą i sercem sługa” księcia Dobrodzieja.

Zanim Linowski opuścił rodzinne strony, aby w środowisku warszawskim rozpocząć i rozwijać spektakularną karierę urzędniczą, jego zbliżenie się do Czartoryskich wynikało zapewne z poczucia osamotnienia w kręgu krakowskim po opuszczeniu stolicy, gdzie był w ostatniej dekadzie XVIII wieku ważną postacią. Poza tym bliski kontakt towarzyski oraz intelektualny z członkami jednej z najznakomitszych rodzin w kraju, a zwłaszcza z tak wybitną osobistością jak książę Adam Kazimierz, po prostu imponował Linowskiemu, którego próżność podkreślali obaj pamiętnikarze epoki - Julian Ursyn Niemcewicz i Kajetan Koźmian. Zachowane listy wyraźnie świadczą, że dokładał wszelkich starań, aby te bliskie relacje nie tylko podtrzymywać, ale też pogłębiaći ${ }^{19}$.

18 Zob. T. Ostrowski, Poufne wieści z oświeconej Warszawy. Gazetki pisane z roku 1782, oprac. i wstępem opatrzył R. Kaleta, Wrocław 1972; Korespondencja i gazetki rękopismienne Jędrzeja Kitowicza z lat 1771-1776, oprac. i wyd. T. Ciesielski, S. Górzyński, F. Wolański, Warszawa-Bellerive-sur-Allier 2017.

19 Składam podziękowania Profesorom: Michałowi Baczkowskiemu, Tomaszowi Ciesielskiemu i Dariuszowi Nawratowi za pomoc w konkretyzacji postaci przywołanych w listach Linowskiego. 


\section{BibLIOGRAFIA:}

Aleksandrowicz A., Wprowadzenie do lektury. Patriotyczny etos Świątyni Sybilli, w: Opisy niektórych pamiatek zachowanych w Światyni Sybilli w Putawach, wyd. A. Aleksandrowicz i A. Timofiejew, Warszawa 2010, s. 5-31;

Z kręgu Marii Wirtemberskiej. Antologia, teksty rękopisów wybrała, oprac. i wstępem poprzedziła A. Aleksandrowicz, Warszawa 1978;

Dihm J., Sprawa Konstytucji Ekonomicznej z 1791 r. (Na tle wewnętrznej i zagranicznej sytuacji Polski), Wrocław 1959;

Estreicher K., Tomasz Kajetan Węgierski (1755-1787), w: T.K. Węgierski, Pisma wierszem i proza, z przedmową K. Estreichera, Lwów 1882, s. I-LII;

Korespondencja i gazetki rękopiśmienne Jędrzeja Kitowicza z lat 1771-1776, oprac. i wyd. T. Ciesielski, S. Górzyński, F. Wolański, Warszawa-Bellerive-sur-Allier 2017;

Koźmian K. K., Pamiętniki, t. 2, przedmowa A. Kopacz, wstęp i komentarz J. Willaume, wstęp edytorski, ustalenie tekstu w oparciu o autograf oraz komentarz filologiczny M. Kaczmarek i K. Pecold, Wrocław 1972;

Koźmian K., Pamiętniki obejmujące wspomnienia od roku 1780 do roku 1815, t. 2, Poznań 1858, s. 299-324;

Krakowski B., Oratorstwo polityczne na forum Sejmu Czteroletniego. Rekonesans, Lublin 1968;

Linowski Aleksander (ok. 1759-1820), w: Bibliografia literatury polskiej „Nowy Korbut”, t. 5: Oświecenie. Hasta osobowe I-O, oprac. E. Aleksandrowska z zespołem, red. tomu do r. 1958 T. Mikulski, Warszawa 1967 , s. 261;

Linowski Aleksander, w: Bibliografia literatury polskiej „Nowy Korbut”, t. 6, cz. 2: Oświecenie. Uzupetnienia, indeksy, oprac. E. Aleksandrowska z zespołem, Wrocław 1972, s. 169;

Łukaszewicz W., Targowica i porwstanie kościuszkowskie. Ze studiów nad historia Polski XVIII wieku, Warszawa 1953;

Mazurkowa B., O emocjonalnych i towarzyskich aspektach listów Aleksandra Linowskiego do Adama Kazimierza Czartoryskiego, w: Epistolografia w dawnej Rzeczypospolitej, t. 7: Literatura, historia, jezzyk, red. P. Borek i M. Olma, Kraków 2017, s. 127-140;

Mroczek K., Tytulatura w korespondencji staropolskiej jako problem stosunku między nadawca a odbiorca, „Pamiętnik Literacki” 1978, z. 2, s. 129-146;

Niemcewicz J.U., Pamiętniki czasów moich, t. 2, tekst oprac. i wstępem poprzedził J. Dihm, pierwsze wyd. według obszerniejszej wersji rękopiśmiennej, Warszawa 1957;

Ostrowski T., Poufne wieści z oświeconej Warszawy. Gazetki pisane z roku 1782, oprac. i wstępem opatrzył R. Kaleta, Wrocław 1972;

Pusz W., „Nowy Parnas” przedromantycznej Warszawy. Bruno Kiciński i grono jego wspótpracowników, Wrocław 1979;

Rostworowski E., „Marzenie dobrego obywatela”, czyli królewski projekt Konstytucji, w: idem, Legendy i fakty XVIII w., Warszawa 1963;

Urzędnicy województwa sandomierskiego XVI-XVIII wieku. Spisy, t. 4, z. 3: Matopolska (województwa krakowskie, sandomierskie i lubelskie), oprac. K. Chłapowski, A. Falniowska-Gradowska, red. A. Gąsiorowski, Kórnik 1993;

Waniczkówna H., Czartoryski Adam Kazimierz, w: Polski stownik biograficzny, Kraków 1938, t. 4, s. 255;

Wojtak M., Wybrane elementy staropolskiej etykiety językowej, „Język a Kultura”, t. 6: Polska etykieta jezzykowa, red. J. Anusiewicz i M. Marcjanik, Wrocław 1992, s. 33-40;

Woltanowski A. i Złomska M., Linowski Aleksander, w: Polski stownik biograficzny, Kraków 1972, t. 17, s. 377-381. 
SŁowa klucze: Aleksander Linowski, Adam Kazimierz Czartoryski, korespondencja, Kraków, Puławy

Bożena Mazurkowa

Unknown letters of Aleksander Linowski to Adam Kazimierz Czartoryski

The edition includes a significant „discovery” of four unknown letters written by Aleksander Linowski to Adam Kazimierz Czartoryski found amidst the correspondence of Ludwik Kropiński to Adam Jerzy Czartoryski in the Princes Czartoryski Library in Cracow. The edition contains a short preface.

Born in 1759 in Cracow, Aleksander Linowski was an important and a wellknown figure of public life especially at the time of the Great Sejm, and later during the Duchy of Warsaw and Congress Poland. He was interested in law, politics, and especially literature. He published several occasional works and a couple of his works were published posthumously in the press. He was elected a deputy to the Grodno Sejm of 1784 from the Cracow's district where he was a landowner, and later, as a king's chamberlain, to the Four-Year Sejm. During the proceeding of the latter his function was to be a king's "transmission" to the patriots. It was him who read out an act of insurrection on the Cracow market square on $24^{\text {th }}$ of March in I794. He socialized with Czartoryski family and he was a frequent guest in Sieniawa, where prince Adam Kazimierz spend some of his time and later decided to settle there. These close relations are documented in four newly found letters sent from Cracow to Sieniawa: three of them by the end of 1803 , and the fourth one at the beginning of 1804 .

Key words: Aleksander Linowski, Adam Kazimierz Czartoryski, correspondence, Cracow, Puławy 